\title{
Peramalan Produksi Perikanan Budidaya di Kabupaten Malang Dengan Metode Exponential Smoothing
}

\author{
[Forecasting of Aquaculture production in Malang Regency using \\ Exponential Smoothing Method]
}

\author{
Febriyani Eka Supriatin', Ahmad Nur Rohman² \\ ${ }^{1}$ Program Studi Budidaya Perairan Fakultas Perikanan dan Ilmu Kelautan Universitas Brawijaya, \\ Jln. Veteran Kota Malang, Indonesia 65149 \\ ${ }^{2}$ Badan Akreditasi Nasional Perguruan Tinggi Kantor Kementerian Pendidikan dan Kebudayaan, Gedung \\ D, Lantai 17, Jalan Pintu I Senayan, Jakarta Indonesia 10270 \\ Email korespondensi: febriyaniekas@ub.ac.id
}

\begin{abstract}
ABSTRAK
Rata-rata konsumsi ikan di Indonesia mencapai $45.99 \mathrm{~kg} /$ kapita dalam 6 tahun terakhir. Hal ini mengakibatkan pemerintah harus bekerja keras untuk mencukupi kebutuhan ikan tersebut. Kondisi iklim dan cuaca saat ini mengalami perubahan yang tidak menentu sangat mempengaruhi hasil perikanan tangkap. Oleh karena itu, pemerintah berusaha meningkatkan subsektor perikanan budidaya untuk mengatasi penurunan produksi ikan. Perikanan budidaya seharusnya dilakukan mengingat Indonesia memiliki lahan yang cukup luas dan penduduk yang banyak. Salah satu wilayah yang sebagian besar rumah tangganya menjadi petani perikanan budidaya adalah Kabupaten Malang. Penelitian ini bertujuan melakukan peramalan hasil produksi ikan budidaya agar dapat dilakukan langkah strategis apabila mendekati batas waktu yang ditentukan belum memenuhi target. Metode yang digunakan adalah metode simple exponential smoothing. Data yang digunakan sebanyak 18 data dari tahun 2001 sampai 2018 yang didapatkan dari Kabupaten Malang Dalam Angka. Evaluasi hasil peramalan dilakukan dengan menghitung nilai rata-rata error dengan menggunakan metode Mean Absolut Percentage Error (MAPE). Hasil penelitian menunjukkan bahwa nilai MAPE model peramalan produksi perikanan budidaya Kabupaten Malang sebesar $17 \%$ (kategori baik=10\%-20\%). Hasil peramalan produksi perikanan budidaya di Kabupaten Malang tahun 2019 adalah sebesar 17798.16 ton.
\end{abstract}

Kata kunci: Konsumsi Ikan, Perikanan Budidaya, Simple Exponential Smoothing, Mean Absolut Percentage Error (MAPE)

\section{ABSTRACT}

The average fish consumption in Indonesia reached $45.99 \mathrm{~kg} / \mathrm{capita}$ in the last 6 years. This resulted the government having to work hard to meet the needs of the fish. The current climatic and weather conditions undergoing uncertain changes greatly affect on the outcome of capture fishery production. Therefore, the government is trying to improve in the aquaculture subsector to solve decreasing of fishery production. Aquaculture industry should be done considering that Indonesia has big potentially areas for aquaculture and a large population. One of the areas where most of the households are aquaculture farmers is Malang Regency. The aims of this study is to forecast the aquaculture production so that strategic steps can be taken if approaching the specified deadline does not meet the target. The method used is the simple exponential smoothing method. The data used were 18 data from 2001 to 2018 obtained from Malang Regency in Figures. Evaluation of forecast of aquaculture production results is calculated by using the Mean Absolute Percentage Error (MAPE) method. The results showed that, the MAPE value of aquaculture production in Malang Regency was 17\% (high categorized=10\%-20\% MAPE value). Results of forecasting aquaculture production in Malang Regency in 2019 was 17798.16 tons.

Keywords: Fish Consumption, Aquaculture, Simple Exponential Smoothing, Mean Absolute Percentage Error (MAPE)

\section{PENDAHULUAN}

Ikan merupakan salah satu sumber pangan di Indonesia. Ikan memiliki kandungan protein, vitamin, dan mineral tinggi yang baik untuk kesehatan sehingga banyak diminati masyarakat (susanto \& Fahmi, 2012). Berdasarkan data dari FAO diprediksikan bahwa konsumsi ikan dunia akan mencapai $22.5 \mathrm{~kg} / \mathrm{kapita}$ per tahun, sedangkan konsumsi ikan di Indonesia sendiri lebih banyak dari itu. Rata - rata konsumsi ikan di Indonesia perkapita dalam 6 tahun terakhir adalah 45.99 kg. Hal ini menunjukkan bahwa konsumsi ikan di Indonesia sangat tinggi. Sedangkan target pemerintah pada tahun 2020 adalah 56.39 $\mathrm{kg} / \mathrm{kapita}$ dan $62.5 \mathrm{~kg} / \mathrm{kapita}$ pada tahun 2024 (Kementrian Kelautan dan Perikanan, 2020).

Untuk mencukupi kebutuhan ikan yang tinggi maka pemerintah harus berusaha keras untuk menyiapkan ketersediaan ikan yang banyak. Akan tetapi pada saat ini banyak kendala yang harus dihadapi oleh para penyedia ikan terutama yang bersumber dari perikanan tangkap. Jumlah ikan yang ada dilaut semakin 
lama semakin sedikit karena over fishing serta kondisi iklim dan cuaca yang berubah-ubah sangat mengganggu nelayan pada saat melakukan pencarian ikan (Azizi, Putri, \& Fahrudin, 2017). Akibatnya produksi perikanan tangkap fluktuatif. Rata-rata hasil produksi perikanan tangkap Kabupaten Malang dalam 3 tahun terakhir sebesar 12597.57 ton. Hasil tahun 2018 sebesar 16526.41 ton, tahun 2017 sebesar 13833.52 ton dan tahun 2016 sebesar 7432.39 ton (hasil ini turun drastis dari tahun 2015 yaitu 11727.62 ton). Perikanan tangkap di kabupaten Malang fluktuatif terutama apabila terjadi gejala alam dan iklim serta cuaca yang tidak menentu sehingga perlu dilakukan usaha agar kebutuhan ikan dapat terpenuhi. Salah satu usaha yang dapat dilakukan adalah meningkatkan sektor lain yaitu perikanan budidaya.

Indonesia memiliki lahan yang cukup luas untuk kegiatan perikanan budidaya (Haris \& Anwar, Syaeful, 2017). Banyak sekali rumah tangga budidaya ikan di Indonesia, salah satu daerah yang memiliki jumlah rumah tangga budidaya yang cukup banyak adalah di Kabupaten Malang. Berdasarkan data Kabupaten Malang dalam angka, semua kecamatan di Kabupaten Malang memiliki rumah tangga perikanan budidaya. Pada tahun 2018 ada sebanyak 5491 rumah tangga perikanan budidaya di Kabupaten Malang. Sedangkan produksi perikanan budidaya di Kabupaten Malang rata-rata dalam 4 tahun terakhir dari tahun 2015 sampai 2018 adalah 19028.55 ton.

Hasil produksi perikanan budidaya pada data tahun terakhir yaitu tahun 2018 adalah sebesar 17798.19. Hal itu tentu saja menjadi sebuah pekerjaan bagi pemerintah karena jumlah produksi perikanan budidaya berada dibawah rata-rata produksi dalam 4 tahun terakhir. Oleh karena itu sangat diperlukan untuk mengetahui kondisi produksi perikanan budidaya agar bisa dilakukan langkah-langkah yang tepat untuk meningkatkan produksi perikanan budidaya sehingga dapat menyuplai ketersediakan ikan nasional.

Untuk mengetahui kondisi hasil produksi perikanan budidaya diperlukan suatu metode peramalan yang bisa mengetahui/memprediksi hasil produksi perikanan tersebut dengan akurasi yang tepat. beberapa penelitian mengenai peramalan telah dilakukan diantaranya, Ikhsan, et al (2019) melakukan peramalan penjualan bakso dengan menggunakan metode simple exponential smoothing dan menghasilkan kesimpulan bahwa metode tersebut dapat memprediksi penjualan bakso dengan baik di bulan berikutnya. Kemudian Putro, et al (2018) memprediksi jumlah kebutuhan pemakaian air menggunakan metode exponential smoothing dengan studi kasus pada PDAM Kota Malang yang menghasilkan bahwa metode single exponential smoothing memiliki prediksi yang lebih baik dibandingkan double exponential smoothing dan triple exponential smoothing. Selain itu penggunaan metode single exponential smoothing dalam bidang pertanian diantaranya oleh Pramayudha (2019) menyimpulkan bahwa metode single exponential smoothing merupakan metode paling akurat dibandingkan metode single moving average dalam memprediksi hasil tanaman pangan. Akolo (2019) membandingkan metode exsponential smooting holt- winter dengan ARIMA pada peramalan produksi padi di Provinsi Gorontalo dan menyimpulkan bahwa metode exsponential smooting memberikan hasil peramalan yang lebih baik dari ARIMA.

Beberapa penelitian yang telah dilakukan menggunakan metode exponential smoothing menghasilkan nilai peramalan yang akurat, maka penulis akan memprediksi jumlah produksi perikanan budidaya di Kabupaten Malang menggunakan metode exponential smoothing. Judul penelitian yang akan dilakuakan yaitu "Peramalan Produksi Perikanan Budidaya dengan Metode Exponensial Smoothing di Kabupaten Malang. Penelitian ini bertujuan untuk mendapatkan prediksi jumlah produksi perikanan budidaya pada tahun 2019 di Kabupaten Malang. Selain itu penelitian ini diharapkan agar bisa membantu pemerintah pusat maupun daerah dalam mempersiapkan ketersedian ikan supaya tidak terjadi kelebihan atau kekurangan ketersediaan ikan pada tahun-tahun berikutnya dengan menggunakan data tahun sebelumnya.

\section{BAHAN DAN METODE}

Penelitian ini menggunakan data sekunder yang bersumber dari Badan Pusat Statistik Kabupaten Malang. Data yang digunakan adalah data jumlah hasil produksi perikanan budidaya Kabupaten Malang dari tahun 2001 sampai dengan tahun 2018. 
Sedangkan analisis yang digunakan adalah metode peramalan menggunakan exponential smoothing. Adapun metode exponential smoothing yang digunakan adalah simple exponential smoothing.

\section{Perikanan Budidaya}

Perikanan budidaya merupakan hasil produksi ikan yang diperoleh melalui cara budidaya di ladang, di sawah atau ditempat lain yang berada di daratan. Ada beberapa definisi terkait perikanan budidaya antara lain: Menurut Badan Pusat Statistik Kabupaten Malang (2019), Perikanan budidaya diklasifikasikan atas jenis budidaya yaitu budidaya laut, tambak, kolam. Karamba, jarring apung dan sawah.

Berdasar Undang-undang Republik Indonesia Nomor 31 Tahun 2004 pembudidayaan ikan merupakan aktivitas untuk memelihara, membesarkan, dan/atau membiakkan ikan serta memanen hasilnya dalam lingkungan yang terkontrol, termasuk aktivitas yang menggunakan kapal untuk memuat, mengangkut, menyimpan, mendinginkan, menangani, memasak, dan atau mengawetkannya.

Perikanan budidaya adalah budidaya organisme air, termasuk ikan, moluska, kurstasea dan flora air yang mencakup beberapa bentuk kegiatan dalam proses pemeliharaan untuk menaikkan produksi, seperti penebaran yang teratur, hadiah kuliner/pakan, perlidungan berdasarkan predator dan lain-lain (Food and Agriculture Organization of the United Nations, 1988).

\section{Simple exponential smoothing}

Metode exponential smoothing merupakan salah satu analisis deret waktu yang sering digunakan karena sederhana dan memiliki hasil yang bagus. Pada metode ini melibatkan pengamtan sebelumnya untuk meramalkan pada tahun berikutnya sehingga data yang diperlukan tidak boleh kosong pada waktu tertentu (Raihan, Eff, \& Hendrawan, 2016). Metode ini mengasumsikan bahwa data akan berfluktuasi di wilayah mean yang tetap tanpa trend atau pola pertumbuhan konsisten. (Makridakis, 1999). Sehingga metode ini sangat sesuai apabila digunakan untuk data yang tidak memiliki trend dan tidak berpola musiman. Ada pun formula yang digunakan untuk metode Simple exponential smoothing adalah sebagai berikut.

$$
F_{\tau}=\alpha X_{\tau}+(1-\alpha) F_{\tau-1}
$$

Dengan: $F_{t}=$ Peramalan untuk periode t, $X_{t}=$ Nilai aktual pada waktu $\mathrm{t}-1, F_{t-1}=$ Peramalan untuk periode t-1, dan $\alpha=$ Parameter exponential dengan nilai $0<\alpha<1$

\section{Mean Absolute Percentage Error (MAPE)}

Salah satu kriteria yang sering digunakan untuk melihat akurasi dari metode peramalan atau analisis runtun waktu yaitu dengan melihat nilai Mean Absolute Percentage Error (MAPE). Hal itu dikarenakan MAPE dapat memberikan hasil yang relatif akurat. Kriteria akurasi dengan menggunakan MAPE ada 4 kriteria (Chang, Wang, \& Liu, 2007). Secara lebih detail untuk kategori nilai MAPE dapat dilihat pada Tabel 1.

Tabel 1. Kriteria Nilai MAPE

\begin{tabular}{cc}
\hline Nilai MAPE & Kriteria \\
\hline$<10 \%$ & Sangat Baik \\
$10 \%-20 \%$ & Baik \\
$20 \%-50 \%$ & Cukup \\
$>50 \%$ & Buruk \\
\hline
\end{tabular}

\section{Mean Absolute Deviation (MAD)}

Mean Absolute Deviation diperoleh dengan cara merata-ratakan nilai absolut error (penyimpangan) seluruh hasil peramalan. Nilai absolut digunakan agar penyimpangan positif dan penyimpangan negative saling meniadakan. Cara menghitung MAD yaitu sebagai berikut.

$$
M=\frac{\sum_{t=1}^{n}\left|X_{t}-F_{t}\right|}{n}
$$

Dengan $F_{t}=$ Peramalan pada periode t, $X_{t}=$ Nilai aktual pada periode $\mathrm{t}, \mathrm{n}=$ Jumlah data

\section{Mean Squared Deviation (MSD)}

MSD merupakan ukuran penyimpangan ramalan dengan cara merata-ratakan kuadrat error penyimpangan semua ramalan. MSD dapat dicari dengan cara

$$
M=\frac{\sum_{t=1}^{n}\left(Y_{(t)}-Y_{(t)}^{\prime}\right)^{2}}{n}
$$

Dengan $Y_{(t)}=$ Nilai aktual pada periode $\mathrm{t}$, $Y^{\prime}{ }_{(t)}=$ peramalan pada periode $\mathrm{t}, \mathrm{n}=$ Jumlah data

\section{HASIL}

Hasil penelitian ini terdiri dari dua yaitu analisis deskriptif dan analisis peramalan. Analisis deskriptif menggambarkan bagaimana 
hasil produksi perikanan budidaya setiap tahun di Kabupaten Malang dari tahun 2001 sampai dengan tahun 2018. Adapun grafik dari hasil produksi perikanan budaya tersebut disajikan pada Gambar 1. Kemudian dari hasil produksi perikanan budidaya terdiri dari beberapa jenis budidaya antara lain tambak, kolam, jaring apung dan sawah disajikan pada Gambar 2.

Hasil yang diperoleh untuk nilai parameter exponential dengan cara mencoba nilai $\alpha$ antara 0 dan 1 di tunjukkan pada Tabel 2. Ukuran ketepatan yang lebih sering digunakan yaitu MAPE karena MSD dan MAD dapat menimbulkan masalah yaitu tidak memudahkan dalam membandingkan antar deret berskala yang berbeda dan selang waktu yang berlainan (Sungkawa, I dan Megasari, R T, 2011). Sehingga dari Tabel 2 dipilih $\alpha$ yang mempunyai nilai MAPE paling kecil yaitu $\alpha=0.95$. Selanjutnya dengan menggunakan $\alpha=0.95$ diperoleh nilai MAPE, MAD, dan MSD sebagai berikut.

\begin{tabular}{lc}
\hline Data & Perikanan Budidaya \\
Length & 18 \\
Smoothing & Constant \\
Alpha & 0,95 \\
Accuracy & Measurs \\
MAPE & 17 \\
MAD & 1394 \\
MSD & 8473439 \\
\hline
\end{tabular}

Sedangkan hasil prediksi perikanan budidaya yang diperoleh dengan $\alpha=0.95$ disajikan pada Tabel 3. Dari hasil peramalan yang telah diperoleh sampai dengan tahun 2018 dan dengan $\alpha=0.95$ maka dapat diprediksi 1 tahun berikutnya dengan hasil sebagai berikut.

\begin{tabular}{cccc}
\hline Period & Forecast & Lower & Upper \\
\hline 2019 & 17780,3 & 14366,2 & 21194,4 \\
\hline
\end{tabular}

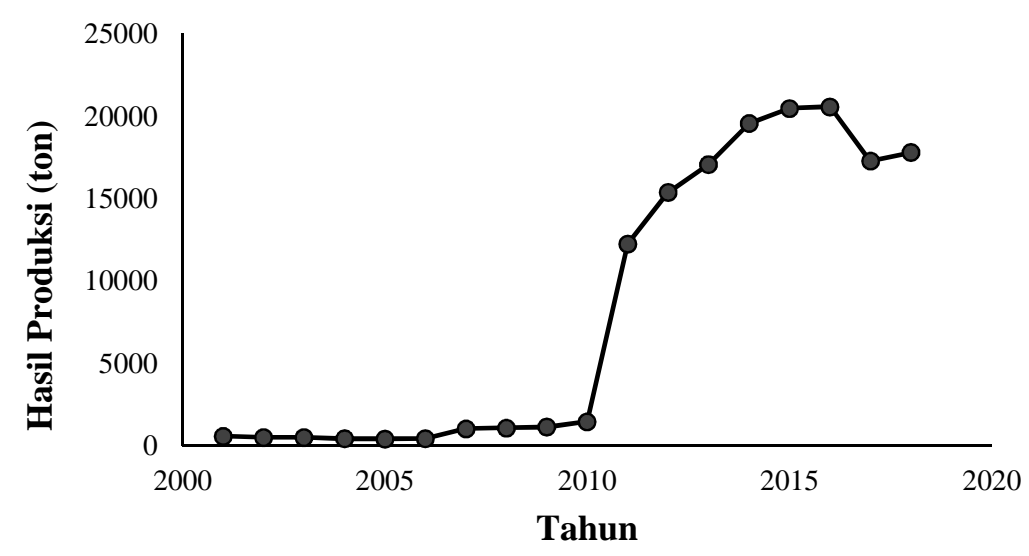

Gambar 1. Hasil Produksi Perikanan Budidaya Kabupaten Malang tahun 2001 sampai dengan 2018 (Sumber: Dinas Perikanan Kabupaten Malang).

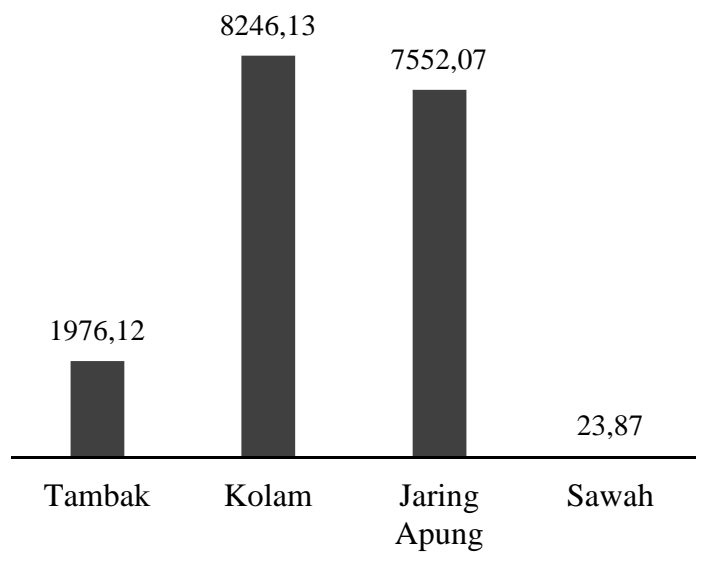

Gambar 2. Jenis Hasil Produksi Perikanan Budidaya Kabupaten Malang tahun 2018. 
Tabel 2. Uji Coba Nilai Alpha

\begin{tabular}{cccc}
\hline Alpha $(\boldsymbol{\alpha})$ & Nilai MAPE & Nilai MAD & Nilai MSD \\
\hline 0,1 & 46 & 5581 & 69073993 \\
0,2 & 37 & 4119 & 41079273 \\
0,3 & 31 & 3127 & 27535272 \\
0,4 & 27 & 2638 & 20222545 \\
0,5 & 25 & 2308 & 15846713 \\
0,6 & 23 & 2026 & 13018563 \\
0,7 & 21 & 1789 & 11099685 \\
0,8 & 19 & 1592 & 9763905 \\
0,9 & 18 & 1448 & 8827779 \\
0,95 & 17 & 1394 & 8473439 \\
\hline
\end{tabular}

Tabel 3. Hasil Prediksi Produksi Perikanan Budidaya

\begin{tabular}{|c|c|c|c|c|}
\hline Tahun & $\begin{array}{l}\text { Hasil Perikanan } \\
\text { Budidaya (ton) }\end{array}$ & Smooth & Predict & Error \\
\hline 2001 & 588,8 & 583,9 & 490,3 & 98,6 \\
\hline 2002 & 517,9 & 521,2 & 583,9 & -66 \\
\hline 2003 & 517,9 & 518,1 & 521,2 & $-3,3$ \\
\hline 2004 & 435,9 & 440 & 518,1 & $-82,2$ \\
\hline 2005 & 428,7 & 429,3 & 440 & $-11,3$ \\
\hline 2006 & 452,5 & 451,3 & 429,3 & 23,2 \\
\hline 2007 & 1040,9 & 1011,4 & 451,3 & 589,5 \\
\hline 2008 & 1086,1 & 1082,4 & 1011,4 & 74,7 \\
\hline 2009 & 1143 & 1139,9 & 1082,4 & 60,6 \\
\hline 2010 & 1469,3 & 1452,8 & 1139,9 & 329,4 \\
\hline 2011 & 12237,5 & 11698,3 & 1452,8 & 10784,7 \\
\hline 2012 & 15380,8 & 15196,6 & 11698,3 & 3682,5 \\
\hline 2013 & 17070,2 & 16976,5 & 15196,6 & 1873,5 \\
\hline 2014 & 19555,8 & 19426,9 & 16976,5 & 2579,4 \\
\hline 2015 & 20476,9 & 20424,4 & 19426,9 & 1050 \\
\hline 2016 & 20562,5 & 20555,6 & 20424,4 & 138,1 \\
\hline 2017 & 17276,6 & 17440,5 & 20555,6 & $-3279,1$ \\
\hline 2018 & 17798,2 & 17780,3 & 17440,5 & 357,7 \\
\hline
\end{tabular}

\section{PEMBAHASAN}

\section{Analisis Deskriptif}

Kabupaten Malang merupakan salah satu kabupaten di Jawa Timur yang memiliki luas wilayah terluas kedua setelah Kabupaten Banyuwangi. Luas wilayahnya yaitu 2977.05 $\mathrm{km}^{2}$ (BPS Kabupaten Malang, 2019). Kabupaten Malang yang terdiri dari 33 kecamatan memiliki letak yang strategis dan kondisi topografi yang bermacam-macam antara lain pegunungan, perbukitan, dataran rendah dan pesisir pantai. Kondisi ini sangat memberikan keuntungan tersendiri bagi Kabupaten Malang. Banyak sektor yang bisa dikembangkan disemua wilayah salah satunya adalah sektor perikanan. Wilayah di Kabupaten Malang yang berbatasan dengan laut hanya beberapa kecamatan sehingga untuk meningkatkan sektor perikanan, pemerintah tidak hanya bergantung pada perikanan tangkap di laut dikarenakan dengan cuaca yang tidak menentu dan ekstrem akan memberikan hasil produksi yang tidak menentu. Salah satu langkah yang bisa diambil yaitu dengan mengembangkan perikanan budidaya.

Kondisi topografi Kabupaten Malang beranekaragam sehingga pemerintah bisa meningkatkan masing-masing wilayah dengan jenis perikanan budidaya yang sesuai. 
Berdasarkan data Badan Pusat Statistik Kabupaten Malang (Gambar 1) terlihat bahwa pada hasil produksi perikanan budidaya tahun 2001 sampai dengan tahun 2010 masih di bawah 1500 ton per tahun. Kemudian mengalami peningkatan yang sangat signifikan pada tahun 2011, pada tahun 2012 sampai dengan 2016 mengalami peningkatan dan mempunyai hasil produsi tertinggi yaitu sebesar 20562.54 ton. Akan tetapi pada tahun 2017 mengalami sedikit penurunan menjadi 17276.57 ton. Dan pada tahun 2018 kembali mengalami sedikit kenaikan menjadi 17798.19 ton. Sedangkan rata-rata hasil produksi perikaanan budidaya dari tahun 2001 sampai 2018 sebesar 8224.41 ton. Perikanan budidaya yang ada di Kabupaten Malang meliputi tambak, kolam, jaring apung dan sawah. Pada tahun 2018 jumlah hasil produksi perikanan budidaya sebesar 17798.19 terdiri dari hasil kolam sebesar 8246.13 ton, dari hasil tambak 1976.12 ton, jaring apung sebesar 7552,07 ton dan sawah sebesar 23.87 ton.

Perikanan budidaya yang sudah ada di seluruh kecamatan di Kabupaten Malang hanya budidaya kolam sedangkan yang lain hanya ada di beberapa kecamatan sehingga pemerintah masih bisa mengembangkan budidaya yang lain terutama yang belum ada yaitu budidaya laut dan keramba. Sedangkan luas lahan yang dimiliki untuk tambak yaitu 64.9 ha, untuk kolam seluas 207.14 ha, jaring apung seluas 173.64 ha, dan sawah seluas 13.00 ha. Kolam dan jaring apung memiliki kontribusi yang besar dalam hasil produksi budidaya perikanan. Kabupaten Malang memiliki sumber daya manusia yang lebih dibidang budidaya perikanan, hal itu terbukti hampir semua kecamatan di Kabupaten Malang mempunyai rumah tangga yang menjadi petani perikanan budidaya terutama budidaya kolam sebanyak 3427 rumah tangga. Selain itu rumah tangga yang bergerak di jaring apung 2000 rumah tangga yang hanya tersebar di 5 kecamatan yaitu Kalipare, Pagak, Pagelaran, sumber pucung dan kromengan sedangkan tambak hanya ada 8 rumah tangga dan sawah 56 rumah tangga.

Perikanan budidaya dipengaruhi oleh beberapa faktor diantaranya luas lahan dan banyaknya pakan yang diberikan (Laksmidevi, $\mathrm{N}$ dan Purwohandoyo, J, 2018), selain itu sumber daya manusia (tenaga kerja) juga berpengaruh terhadap perikanan budidaya (Negara, Setiawina, \& Dewi, 2017) karena akan memudahkan pengelolaan dan peningkatan kualitas hasil perikanan budidaya terutama untuk perikanan budidaya yang memiliki lahan yang sangat luas. Pemerintah bisa meningkatkan luas lahan yang ada untuk menunjang peningkatan perikanan dan bisa menambahkan jenis budidaya yaitu budidaya laut dan keramba yang belum ada di Kabupaten Malang.

Selain itu subsektor perikanan budidaya juga sangat penting karena bisa memberikan dampak terhadap kondisi lingkungan dan sosial ekonomi masyarakat. Penelitian Putri, et al (2014) menyimpulkan bahwa usaha budidaya perikanan dapat meningkatkan penghasilan dan hubungan/interaksi masyarakat. Sehingga diharapkan dengan meningkatnya hasil produksi perikanan budidaya masyarakat menjadi lebih meningkat pendapatannya terutama untuk daerah yang sekarang ini masih dalam kondisi kekurangan. Kemudian berdasarkan penelitian Zulkarnain, $\mathrm{M}$ et al (2013) menghasilkan bahwa nilai produksi dari budidaya kolam, budidaya laut dan budidaya tambak memiliki pengaruh positif terhadap produk domestik bruto sektor perikanan di Indonesia sehingga dengan meningkatnya hasil produksi perikanan budidaya dapat membantu pemerintah dalam meningkatkan pendapatan daerah.

\section{Analisis Peramalan}

Peramalan merupakan salah satu teknik yang dapat digunakan untuk memprediksi suatu nilai dimasa yang akan datang dengan memanfaatkan data atau informasi di masa lalu untuk acuan penyusunan perencanaan dan pengambilan keputusan. Peramalan yang digunakan dalam penelitian ini menggunakan exponential smoothing karena metode ini memiliki perhitungan yang sederhana dan keakuratan yang lebih baik. Gustriansyah, R (2017) menyimpulkan bahwa metode exponential smoothing memiliki kesalahan prediksi lebih rendah dibandingkan dengan presentase kesalahan prediksi rata-rata dengan menggunakan metode Brown exponential smoothing. Selain itu dilihat dari karakteristik data yang berfluktuasi dengan tidak ada trend maupun pola musiman pada data, maka simple exponential smoothing sangat sesuai. Metode 
simple exponential smoothing dimulai dengan menentukan nilai parameter exponential $(\alpha)$.

Penelitian menggunakan simple exponential smoothing juga digunakan oleh Khotimah, et al (2014) untuk memprediksi persediaan ikan teri. Penelitian ini menghasilkan kesimpulan bahwa dengan metode tersebut diperoleh nilai akurasi $10 \%$ dan 20\% sehingga hasil peramalan mendekati hasil yang sebenarnya. Selain itu Pramayoga (2017) juga melakukan penelitian dengan metode single exponential smoothing dan diperoleh hasil bahwa metode tersebut memiliki nilai uji kesalahan terkecil dibandingkan metode lainnya dalam memprediksi ketersediaan ikan hasil tangkapan.

Hasil pengolahan pada penelitian ini menunjukkan bahwa dengan default pada software diperoleh nilai $\alpha$ sebesar 1.28 yang berarti nilai $\alpha$ tidak dapat digunakan karena memiliki nilai lebih dari 1. Metode lain yang dapat digunakan adalah dengan mencoba-coba nilai $\alpha$ antara 0 dan 1 yang memiliki nilai MAPE terkecil. Berdasarkan nilai MAPE terkecil maka $\alpha$ yang digunakan adalah 0.95. Hasil yang diperoleh menunjukkan nilai MAPE sebesar 17 yang berarti bahwa akurasi metode simple exponential smoothing masuk dalam kriteria baik sehingga metode ini akurat untuk meramalkan hasil produksi perikanan budidaya di Kabupaten Malang untuk satu tahun berikutnya dengan menggunakan parameter exponential sebesar 0.95. Metode simple exponential smoothing memanfaatkan data-data sebelumnya sehingga lebih akurat untuk memprediksi jangka pendek. Penelitian ini akan memprediksi hasil produksi perikanan budidaya pada tahun 2019 di Kabupaten Malang.

Hasil pengolahan menggunakan software diperoleh hasil bahwa diprediksikan untuk tahun 2019 hasil produksi perikanan budidaya di Kabupaten Malang sebesar 17780.3 ton. Berdasarkan hasil peramalan tersebut jika dibandingkan dengan tahun 2018 terjadi penurunan produksi perikanan budidaya di Kabupaten malang sehingga pemerintah perlu melakukan antisipasi. Langkah yang dapat dilakukan dapat berupa penyuluhan dan pelatihan pengembangan ilmu pengetahuan dan teknologi perikanan kepada para petani budidaya. Menurut Rahmani et, al (2018) kegiatan tersebut mampu meningkatkan produktifitas perikanan budidaya.

\section{KESIMPULAN}

Nilai parameter exponential yang akurat untuk peramalan hasil produksi perikanan budidaya di Kabupaten Malang adalah $\alpha=0.95$. Kemudian diperoleh nilai MAPE sebesar 17 yang berarti masuk dalam kategori baik sehingga metode simple exponential smoothing baik dan akurat untuk meramalkan hasil produksi perikanan budidaya di Kabupaten Malang. Hasil forecasting (peramalan) hasil produksi perikanan budidaya di Kabupaten Malang untuk satu tahun berikutnya yaitu tahun 2019 adalah 17780.3 ton.

\section{REFERENSI}

Akolo, I. R. (2019). Perbandingan Exponential Smoothing Holt-Winters dan Arima pada Peramalan Produksi Padi di Provinsi Gorontalo. Jurnal Technopreneur, 7(1): 20-26. https://doi.org/10.30869/jtech.v7i1.314

Azizi, Putri, E. I. K., Fahrudin, A. (2017). Analisis Faktor-Faktor yang Mempengaruhi Perubahan Pendapatan Nelayan Akibat Variablitas Iklim. Jurnal Sosial Ekonomi Kelautan dan Perikanan, 12(2): 225-233.

http://dx.doi.org/10.15578/jsekp.v12i2.5 320

Badan Pusat Statistik Kabupaten Malang. 2019. Kabupaten Malang Dalam Angka 2019. BPS Kabupaten Malang. Malang.

Chang, P., Wang, Y. and Liu, C. (2007). The Development of a Weighted Evolving Fuzzy Neural Network for PCB Sales Forecasting. Expert Systems with Applications), 32(1): 86-96. https://doi.org/10.1016/j.eswa.2005.11.02 1

FAO. (1988). The State Food and Agricultural 1987-1988. Rome.

Gustriansyah, R. (2017). Analisis Metode Single Exponential Smoothing Dengan Brown Exponential Smoothing Pada Studi Kasus Memprediksi Kuantiti Penjualan Produk Farmasidi Apotek. Seminar Nasional Teknologi Informasi dan Multimedia, 3.5-7-3.5-12. STMIK AMIKOM. Yogyakarta.

Haris, R. B. K., dan Anwar, S. (2017). Analisis Tingkat Pemanfaatan Lahan, Total Produksi, Dan Produktivitas Ikan 
Bandeng (Chanos chanos Forskal 1775)

Di Kecamatan Tugu Kota Semarang Provinsi Jawa Tengah. Jurnal Ilmu-ilmu Perikanan dan Budidaya Perairan, 12(1): 12-17.

Ikhsan, H., Syam, R., dan Ahmad, F. (2019). Peramalan Penjualan dengan Metode Exponential Smoothing (Studi Kasus: Penjualan Bakso Kemasaan/Kiloan Rumah Bakso Bang Ipul). Jurnal Pengembangan Teknologi Informasi dan Ilmu Komputer, 2(11): 4679-4686.

Kementrian Kelautan dan Perikanan. (2020). 2020, Kkp Targetkan Konsumsi Ikan 56,39 Kg. Siaran Pers. Diakses 4 April. https://kkp.go.id/artikel/16451-2020-kkptargetkan-konsumsi-ikan-56-39-kg.

Khotimah, B. K., Laili, M., Satoto, B. D. (2014). Prediksi Persediaan Ikan Teri Menggunakan ExponentialSmoothing Berbasis Ordered Weighted Aggregation. Jurnal ilmiah NERO, 1(1), 27-32. http://dx.doi.org/10.21107/nero.v1i1.19

Laksmidevi, N dan Purwohandoyo, J. (2018). Faktor-Faktor yang Mempengaruhi Produksi dan Produktivitas Kolam Budidaya Ikan di Kawasan Minapolitan Kecamatan Polanharjo, Kabupaten Klaten (Kasus di Desa Nganjat dan Desa Janti). Jurnal Bumi Indonesia, 7(2), 1-12.

Makridakis, Wheelwright dan McGee. (1999). Metode dan Aplikasi Peramalan (terjemahan). Binarupa Ksara. Jakarta.

Negara, AA. N. B. S., Setiawina, N. D., Dewi, M. H. U. (2017). Faktor-Faktor Yang Mempengaruhi Produksi Budidaya Ikan Lele Di Kota Denpasar. E-Jurnal Ekonomi dan Bisnis Universitas Udayana, 6(2): 755-788.

Pramayoga, B. (2017). Peramalan Ketersediaan Ikan Hasil Tangkapan di PPP Blanakan, Kabupaten Subang. Skripsi. Institut Pertanian Bogor. Bogor.

Pramayudha, M. (2019). Prediksi Hasil Panen Tanaman Pangan Dengan Metode Single Moving Average dan Single Exponential Smoothing. Skripsi. Jurusan Teknik Informatika. Fakultas Sains danTeknologi. Universitas Islam Negeri Maulana Malik Ibrahim. Malang.

Putri, T. D., Priadi, D. P., Sriati. (2014). Dampak Usaha Perikanan Budidaya
Terhadap Kondisi Lingkungan Dan Sosial Ekonomi Masyarakat Pada Lahan Pasang Surut Kabupaten Banyuasin Propinsi Sumatera Selatan. Jurnal Akuakultur Rawa Indonesia, 2(1): 43-54. https://doi.org/10.36706/jari.v2i1.1961

Putro, B., Furqon, M. T., Wijoyo, S. H. (2018). Prediksi Jumlah Kebutuhan Pemakaian Air Menggunakan Metode Exponential Smoothing (Studi Kasus: PDAM Kota Malang). Jurnal Pengembangan Teknologi Informasi dan Ilmu Komputer, 2(11): 4679-4686.

Rahmani, M. R., Noor, M., Hasanah, N. (2018). Peran Dinas Perikanan dalam Pengelolaan Peningkatan Produktivitas Perikanan Pembudidaya Tambak di Kecamatan Babulu Kabupaten Penajam Paser Utara. Journal Ilmu Pemerintahan, 6(3): 1087-1098.

Raihan, Effendi, M. S., Hendrawan, A. (2016). Forcasting Model Exsponensial Smoothing Time Series Rata Rata Mechanical Availability Unit Off Highway Truck Cat 777 d Caterpillar. Jurnal Poros Teknik, 8(1): 1-54. https://doi.org/10.31961/porosteknik.v8i 1.375

Republik Indonesia. (2004). Undang-Undang No. 31 Tahun 2004 tentang Perikanan. Lembaran Negara RI Tahun 2004, No. 118. Sekretariat Negara. Jakarta.

Susanto, E. dan Fahmi, A. S. (2012). Senyawa Fungsional Dari Ikan Aplikasinya Dalam PANGAN. Jurnal Aplikasi Teknologi Pangan, 1(4): 95-102.

Zulkarnain, M., Purwanti, P., Indrayani, E. (2013). Analisis Pengaruh Nilai Produksi Perikanan Budidaya Terhadap Produk Domestik Bruto Sektor Perikanan Di Indonesia. Jurnal ECSOFiM, 1(1): 52-69. 